\title{
Sectors' Export and Economic Growth in Ethiopia: (VECM Causality Approach)
}

\author{
Tesfa-Amlak Gizaw (M.sc.) Tasew Tadesse(Phd) \\ Economics Department, Dilla University, Dilla Ethiopia
}

\begin{abstract}
The link between export and economic growth has been interesting and rich source of debates among economists and many other scholars. Particularly looking depth into the logical disagreement of the scholars; it is revolves mainly around whether export-led growth hypothesis or growth-led export hypothesis hold true in the explicit circumstances for different countries. And this divergence is also the foremost purpose of this work in that the causal relationship between sectors' export and output growth in Ethiopia examined using secondary time series data collected from national bank of Ethiopia, ministry of finance and economic development and World Bank development indicator data base. VECM model used and its result reveal, in the long run the existence of unidirectional causality which run from economic growth to agriculture, industry and service export disjointedly however in the short run it reveal the existence of unidirectional causality which runs solely from economic growth to service export, in other word growth-led export hypothesis supported in case of Ethiopia. Therefore, to further develop and diversify export in Ethiopia, economic growth needs to be strengthening and diversified.
\end{abstract} Keywords: export, economic growth, econometrics, VECM model and causality.

DOI: $10.7176 / \mathrm{JESD} / 11-3-04$

Publication date: February $29^{\text {th }} 2020$

\section{INTRODUCTION}

Countries of the world are interdependent. And one of the means by which countries relay one up on another is trade. International trade has an element of export and import in it. Despite the fact that a country is not self sufficient to meet the total demand of its society with what it produced in the home economy, it may import foreign goods and services from other countries. However to import foreign product, the country must export goods and services to foreigners and get foreign currencies in return. And hence exporting goods and services means acquiring foreign currencies, encouraging economic specialization, rising the productivity of non-export sector, promoting investment, creating employment opportunity, increasing intra trade, reducing the impact of external shocks on domestic economy and then promote economic growth. (Balassa, 1978; Feder, 1982; Smith, 2001; Hock, 2006)

Despite export trade is believed to play crucial role in promoting economic growth for both developed and developing countries. Still there is an increasing interest on the relationship between export and economic growth. In such way for long period of time there has been considerable debate regarding the relationship between the two variables. And five possible relationships had been identified between export and economic growth: viz export driven growth, growth led exports, two way causality, no causal effects and negative connection between them. And theoretically all five results are supported (Pack, 1988; Thornton, 1996).

The export-led hypothesis suggests a sharp growth in output through various avenues. First, an increase in exports facilitates more imports into a country. If these imports include capital and intermediate goods, they would act as a catalyst for higher output growth. Second, export development tends to concentrate investment in the most efficient sectors of the economy where comparative advantage lies. Specialization in these improves productivity in the economy leading to higher output growth. Third, the totaling of international markets to already existing domestic market, gives scope for economies of scale in the export sector. This also pushes up the growth in output. Fourth, export growth represents an increase in aggregate demand, which can serve to increase output. Fifth, exchange control relaxation and the export growth induce lower allocative inefficiencies in the economy, yielding higher output growth. Sixth, higher export growth can lead to higher investment - both local and foreign. Finally, international spread of technology and market innovation which exports capture can have output effects. In general, all these characteristics of export growth tend to reinforce each other stimulating further expansion of exports, investment and consumption. And the final result is a significant rise in the rate of growth of output. (Chu, 1988; Khalafalla and Webb, 2000; Anwar and sampath, 2000; and Dawson, 2005)

The direction of causality from output growth to exports is also plausible. In a growing LDC it is possible that there are some dynamic industries which are expanding rapidly. It is unlikely that domestic demand in these countries will rise as rapidly as output of these industries. Consequently, these domestic producers will explore foreign markets for sales. If this were the case, it is increased output that causes increased exports. Also, higher output growth can stimulate higher investment, part of which can be for increasing the capacity to export. (Ewetan and Okudua, 2012; Ugwuegbe and Uruakpa, 2013; Armand Gilbert, et al 2013)

A feedback relationship between exports and output can also hold under certain cases. Countries exporting 
a large share of their output seem to grow faster than other countries. Putting together the two hypotheses; exports may rise from the realization of economies of scale due to productivity gains; the rise in exports may further enable cost reductions, which may result in further productivity gains. (Idowu, 2005; Rahmaddi, 2011)

With this setting, we are interested to note the link between export and output growth in Ethiopia. The country has been formulating different strategies and undertaking policy changes in different sectors of the economy. Among such changes export promotion strategy occupies the prominent place. And following this strategy the country's economy and its export tangibly had been increasing overtime. For instance according to (world bank, 2016) report “over the past decade Ethiopian's economy has been growing twice the rate of Africa regions, averaging 10.6 percent GDP per year between 2004 and 2011 compared to 5.2 percent in sub-Sahara Africa(SSA). Similarly during the same period export grew by 20 percent with the dominance of primary commodities in general and coffee with 26.4 percent in particular. Despite these figures give evidence regarding the existence of some link relationship between export and economic growth in Ethiopia they can't give surety about whether the export sector has been backing up Ethiopian economy in its double digit growth rate. To this end some authors had examined over the relation between export and growth in the case of Ethiopia. For instance (Tegenu, 2011) examined export- led or domestic demand- led growth policy in Ethiopia. He argued that the current stage of the country's structural transformation requires policy agenda of domestic demand-led growth. (Hailegiorgis, 2012) empirically examined the effects of export led growth (ELG) on Ethiopian economy with the application of Granger (1969) causality test using annual data for the period 1974-2009 and find unidirectional causality from export to economic growth in Ethiopia. (Soressa, 2013) examined relationship between exports, domestic demand and economic growth in Ethiopia using time series data over the period 1960 to 2011. The result revealed a dynamic relationship between export and economic growth and between domestic demand and economic growth. Exports and domestic demands are important for economic growth and economic growth has an impact on exports and domestic demand in Ethiopia.

However empirical studies which have been conducted during the last four decades to investigate the role of exports on economic growth they were conducted along a number of divergent lines. Thus all of the above work is not free from gaps. Loosely speaking the early studies on this issue examined the simple correlation coefficient between export growth and economic growth. The second group of studies took the approach of whether or not exports are driving output by estimating output growth regression equations based on the neoclassical growth accounting techniques of production function analysis, including exports or export growth as an explanatory variable. A third group of, relatively recent, studies have their emphasis on causality between export growth and economic growth. Finally, there have been relatively new studies which involve the application of techniques of co-integration and error-correction models. This relatively new methodology does not suffer from the shortcomings found in methodologies of previous studies. But since these studies which conducted in this method highly concentrated on aggregate export band failed to show the relationship between disaggregate export and economic growth. And hence this study, using VECM causality technique, mainly examined the causal link between disaggregate export and economic growth in Ethiopia.

\section{METHODOLOGY}

\subsection{Type and Source of Data}

A time series secondary data from $1974 / 75$ to $2016 / 17$ is collected from National Bank of Ethiopia (NBE), Ethiopia Revenue and Custom Authority (ERCA), Central Statistics of Authority (CSA), Ministry Finance and Economic development (MoFED) and World Bank (WB) development indicators database

\subsection{Methods of Data Analysis}

The analytical framework of the study is more empirical. Specifically, we employed vector error correction model. This is because the model has gained reputation or ability to guarantee stationarity and to make available extra channels through which bi-directional causality can be examined when two variables are co-integrated.

\subsection{Model specification}

To examine the effect of export on economic growth some theoretical models are considered in this study. The factors of production and the production technology that determine the level of output in an economy can be given as:

$Y_{t}=f\left(A_{t} K_{t} L_{t}\right)=A_{t} K_{t}^{\beta_{1}} L_{t}^{\beta_{2}}$

Where $Y_{t}$ is the production of the economy which is real GDP at time $\mathrm{t} ; A_{t}, K_{t}, L_{t}$, are the total factor productivity, the stock of capital, the stock of labor in the given country respectively.

The second theoretical model considered in this work is the neo-classical growth model modified and suggested by (Balassa, 1978):

$\mathrm{Y}=\mathrm{A} \mathrm{f}(\mathrm{L}, \mathrm{K}, \mathrm{X})$ 
Where $\mathrm{Y}$ is aggregate real output, $\mathrm{K}, \mathrm{L}$ and $\mathrm{X}$ represent capital, labor and export respectively.

Thus, $Y_{t}=K_{t}^{\beta_{1}} L_{t}^{\beta_{2}} \operatorname{RAX}_{t}^{\beta_{3}} \operatorname{RIX}_{t}^{\beta_{4}} \operatorname{RSX}_{t}^{\beta_{5}} E_{t}$

Where $\beta_{1}, \beta_{2}, \beta_{3}, \beta_{4}$ and $\beta_{5}$ are constant elasticity coefficients of output with respect to $\mathrm{K}, \mathrm{L}, \mathrm{RAX}$, RIX and RSX is exogenous components of growth. That means it consists of any variable that affect growth but not included in the model as explanatory variable.

From the equation above after taking $\log$ in both sides, the equation now becomes:

$$
\ln \mathrm{Y}_{\mathrm{t}}=\beta_{0}+\beta_{1} \ln K_{t}+\beta_{2} \ln L_{t}+\beta_{3} \ln \mathrm{RAXt}+\beta_{4} \ln \mathrm{RIXt}+\beta_{5} \ln \mathrm{RSXt}+\varepsilon_{t}
$$

Where, $\mathrm{LRGDP}=$ Real GDP at time $\mathrm{t}$ in $\log$ form is the dependent variable.

$\mathrm{LRAX}=\log$ of real agricultural export at time $\mathrm{t}$

LRIEXP $=\log$ of real industry export at time $\mathrm{t}$

LRSX $=\log$ of real service export at time $t$

Where $\varepsilon_{t}$ is the white noise error term that is the error term which satisfies the assumption of Classical linear Regression Model (CLRM)

\subsection{Estimation Technique}

\subsubsection{Unit root test}

Working with non-stationary variables lead to spurious regression results, from which further inference is meaningless. Thus, it is better to distinguish between stationary and non-stationary variables. The most common example of a stationary series is the white noise which has a mean of zero, a constant variance and a zero covariance between successive terms.

The ADF test assumes that the errors are statistically independent and have a constant variance. Thus, an error term should be uncorrelated with the others, and has a constant variance. The test is first carried out with a constant and trend on the variable in level form. Secondly, it is carried out with a constant only and finally without constant or trend, on the differenced variable depending on which was significant in the level form.

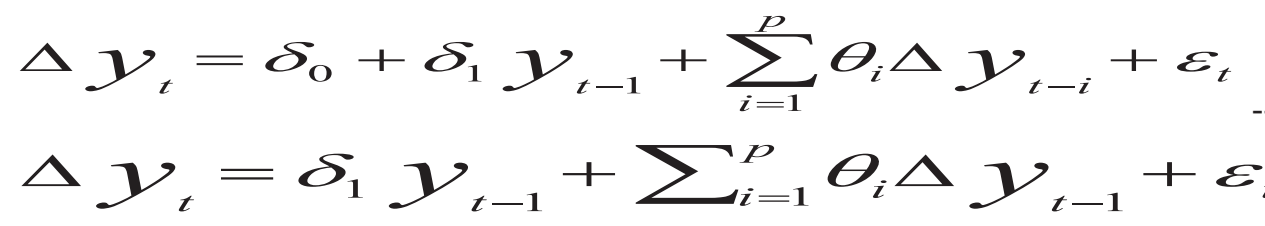

Where, $\delta_{0}$ and $t$ are the constant and the time trend, respectively. If dependent and independent variables failed the stationarity test, the data generating process of these variables are non-stationary. These tests are performed on both level form and first differences of both variables. In a situation where all the variables are stationary at I (0), the OLS method is used in the estimation. Implications of the unit root test result on the estimation procedures are; if all variables in the equation are found to be non-stationary at level form but stationary at first difference I (1), then co-integration test is conducted to find the existence of a long-run equilibrium relationship.

\subsubsection{Co-integration Test}

The theory of co-integration can be used to study series that are non-stationary but a linear combination of which is stationary. Co integration is the statistical implication of the existence of long run relationship between the variables which are individually non-stationary at their level form but stationary after difference (Gujarati, 1995). Two main procedures can be used to test for co-integration: The (Engle and Granger, 1987) test and the (Johansen, 1988) co-integration test. Johansen procedure of co integration gives two statistics. These are the value of LR test based on the maximum Eigen - value and on the trace value of the stochastic matrix. The Johansen test uses the likelihood ratio to test for co-integration. And up to ( $\mathrm{r}-1$ ) co-integrating relationships may exist between a set of $r$ variables. The decision rule compares the likelihood ratio to the critical value for a hypothesized number of co-integrating relationships. If the likelihood ratio is greater than the critical value, the hypothesis of co-integration is accepted.

Besides if two variables $\mathrm{Y}$ and $\mathrm{X}$ are cointegrated, then the long term or equilibrium relationship that exists between the two can be expressed as ECM (Gujarati, 2004). This means one will go for the construction of an error correction model if and only if the two variables are cointegrated. The ECM can be given by:

$\Delta Y_{t}=\alpha_{0}+\alpha_{1} \Delta X_{t}+\alpha_{2} u_{t-1}+\varepsilon_{t}$

Where $\Delta$ denotes the first difference operator, $\varepsilon_{t}$ is a random error term, and $u_{t-1}=$ $\left(Y_{t-1}-\beta_{1}-\beta_{2} X_{t-1}\right)$, that is, the one-period lagged value of the error term from the cointegrating regression.

This ECM equation states that $\Delta \mathrm{Yt}$ depends on $\Delta \mathrm{Xt}$ and also on the equilibrium error term. If the latter is nonzero, the model is out of equilibrium. Suppose $\Delta \mathrm{Xt}$ is zero and $\mathrm{u}_{\mathrm{t}-1}$ is positive. This means $\mathrm{Y}_{\mathrm{t}-1}$ is too high 
[above] to be in equilibrium. Since $\alpha_{2}$ is expected to be negative, the term $\alpha_{2} u_{t-1}$ is negative and, therefore, $\Delta Y t$ will be negative to restore the equilibrium. That is, if $\mathrm{Yt}$ is above its equilibrium value, it will start falling in the next period to correct the equilibrium error; hence the name ECM. By the same token, if $u_{t-1}$ is negative (i.e $\mathrm{Yt}$ is below its equilibrium value), $\alpha_{2} u_{t-1}$ will be positive, which will cause $\Delta \mathrm{Yt}$ to be positive, leading $\mathrm{Yt}$ to rise in period $t$. The absolute value of $\alpha_{2}$ determines how quickly the equilibrium is restored. In practice $u_{t-1}$ will be estimated by $\hat{u}_{t-1}=Y_{t}-\hat{\beta}_{1}-\hat{\beta}_{2} X_{t}$ (Gujarati, 2004).

\subsubsection{VECM and Causality}

In a setting where the variables are non-stationary at level, as is the case with most economic time series (Engle and Granger, 1987) argue that the conventional Granger causality tests could provide misleading results. This is because the conventional Granger causality test ignores the long run equilibrium relationships implied by the cointegration properties of the time series, and hence omits an important channel through which causality may be detected. In this case the recommended approach to testing for the Granger causality is the Co-integration and Error-Correction framework. As opposed to the conventional Granger causality test, an error-correction model combines the short run dynamics with the long run properties of the data and thus provides a convenient tool for investigating short run as well as long run causal patterns. The error-correction models are formulated as follows:

$$
\begin{aligned}
& (1-L) y_{t}=c_{1}+d_{1} \varepsilon_{t-1}+\sum_{i=1}^{p} \delta i(1-L) y_{t-i}+\sum_{i=1}^{h} \theta i(1-L) x_{t-i}+\mu_{t} \\
& (1-L) x_{t}=c_{2}+d_{2} \varepsilon_{t-1}^{\prime}+\sum_{i=1}^{m} i(1-L) x_{t-i}+\sum_{i=1}^{n} \lambda i(1-L) y_{t-i}+v_{t}
\end{aligned}
$$

Where, $\mathrm{L}$ is the lag operator and the error-correction terms $\varepsilon$ and $\varepsilon^{\prime}$ are the stationary residuals from the cointegration equations. These terms re-introduce the long run information in the levels of the variables that is lost in first differencing, and thus provide an additional channel, the adjustment of variables towards a long run equilibrium, through which causality can be detected. For instance, in equation (8), y is said to Granger-cause $\mathrm{x}$, not only if the $\theta_{i}$ 's are jointly significant, but also if $\mathrm{d}_{\mathbf{1}}$ is significant. Therefore, in contrast to the standard Granger test, as long as the error-correction term has a significant coefficient, the error-correction model allows for the possibility that $y$ Granger-causes $x$ even if the $\theta_{i}$ 's are not jointly significant.

\section{RESULT and DISCUSSION}

\subsection{Unit Root Test Results.}

Table 1: Augmented Dickey-Fuller (ADF) and Phillips-Perron (PP) stationarity test results

\begin{tabular}{|c|c|c|c|c|c|c|}
\hline Variables & $\begin{array}{l}\text { Intercept } \\
\text { No trend }\end{array}$ & $\begin{array}{l}\text { Critical } \\
\text { value }\end{array}$ & $\begin{array}{l}\text { Intercept } \\
\text { And trend }\end{array}$ & $\begin{array}{c}\text { Critical } \\
\text { value }\end{array}$ & prob. & Remarks \\
\hline $\begin{array}{l}\text { LRGDP } \\
\text { LRAX } \\
\text { LRIX } \\
\text { LRSX } \\
\text { LRIM } \\
\end{array}$ & $\begin{array}{l}-2.020151 \\
-6.540730 \\
-6.240128 \\
-7.381334 \\
-8.285444 \\
\end{array}$ & $\begin{array}{l}-3.621023 \\
-3.610453 \\
-3.610453 \\
-3.610453 \\
-3.610453 \\
\end{array}$ & $\begin{array}{l}-6.635440 \\
-6.549601 \\
-6.151209 \\
-7.390909 \\
-8.451934 \\
\end{array}$ & $\begin{array}{c}-4.219126 \\
-4.211868 \\
-4.211868 \\
-4.211868 \\
-4.211868 \\
\end{array}$ & $\begin{array}{c}0.0000 \\
0.0000 \\
0.0000 \\
0.0000 \\
0.0000 \\
\end{array}$ & $\begin{array}{l}\mathrm{I}(1) \\
\mathrm{I}(1) \\
\mathrm{I}(1) \\
\mathrm{I}(1) \\
\mathrm{I}(1)\end{array}$ \\
\hline \multicolumn{7}{|c|}{ PP test statistics } \\
\hline $\begin{array}{l}\text { LRGDP } \\
\text { LRAX } \\
\text { LRIX } \\
\text { LRSX } \\
\text { LRIM }\end{array}$ & $\begin{array}{l}-4.453935 \\
-6.538141 \\
-6.409869 \\
-7.530092 \\
-8.201386\end{array}$ & $\begin{array}{l}-3.610453 \\
-3.610453 \\
-3.610453 \\
-3.610453 \\
-3.610453\end{array}$ & $\begin{array}{l}-6.229825 \\
-6.573942 \\
-6.284100 \\
-7.559470 \\
-8.694209\end{array}$ & $\begin{array}{l}-4.211868 \\
-4.211868 \\
-4.211868 \\
-4.211868 \\
-4.211868\end{array}$ & $\begin{array}{l}0.0000 \\
0.0000 \\
0.0000 \\
0.0000 \\
0.0000\end{array}$ & $\begin{array}{l}\mathrm{I}(1) \\
\mathrm{I}(1) \\
\mathrm{I}(1) \\
\mathrm{I}(1) \\
\mathrm{I}(1)\end{array}$ \\
\hline
\end{tabular}

ADF test statistics

Source: E-views version 7 outputs

Table 1 displays the results of ADF and PP unit root test at both intercept with and without trend. At their levels all-time series have a stochastic trend and indicate that the null hypothesis cannot be rejected for any of the variables under scrutiny. However, when taking their first differences the tests strongly reject the unit root, which means that they are integrated of order one i.e. I (1). 


\subsection{Co-integration Test Result}

\subsubsection{Optimal Lag Length Determination.}

To determine optimal lag length in this study, the Likelihood Ratio test statistics (LR), the Final Prediction Error (FPE), the Akaiki Information Criterion (AIC), the Schwarz Information Criterion (SIC)], and the Hannan-Quinn Information Criterion (HQ) statistics are employed and all them suggest lag length one as maximum lag.(see table 2)

Table 2: Optimal Lag Order Selection Criteria

\begin{tabular}{|c|c|c|c|c|c|c|}
\hline Lag & $\log L$ & LR & FPE & AIC & $\mathrm{SC}$ & HQ \\
\hline 0 & -73.49199 & NA & $3.85 \mathrm{e}-05$ & 4.025230 & 4.238508 & 4.101752 \\
\hline 1 & 82.22218 & $263.5163 *$ & $4.79 \mathrm{e}-08^{*}$ & $-2.678061^{*}$ & $-1.398398 *$ & $-2.218929 *$ \\
\hline 2 & 105.7490 & 33.78216 & $5.51 \mathrm{e}-08$ & -2.602515 & -0.256467 & -1.760773 \\
\hline
\end{tabular}

Note: * indicates lag order selected by the criterion

Table 3: VAR Wald Lag-Exclusion Test

\begin{tabular}{||l|l|l|l|l|l|l||}
\hline \hline & LRGDP & LRAX & LRIX & LRSX & LRIM & Joint \\
\hline \hline & 5265.412 & 223.7582 & 230.6686 & 689.8812 & 984.0292 & 6053.455 \\
Lag 1 & {$[0.000000]$} & {$[0.000000]$} & {$[0.000000]$} & {$[0.000000]$} & {$[0.000000]$} & {$[0.000000]$} \\
\hline \hline df & 5 & 5 & 5 & 5 & 5 & 25 \\
\hline \multicolumn{2}{|l}{ Note: }
\end{tabular}

The Wald Lag-Exclusion Test results in table 3 further confirm the lags with significant information content are not disembodied from the VAR system and portrays that the first lag which is chosen by all lag selection criterions as maximum lag is valid. This implies that the fist lags of all variables, individually and jointly, are significant in the system VAR.

\subsubsection{Johansen Co-integration Test Results}

Since both the trace test statistic and Max-Eigen statistic are greater than the critical values at zero cointegrating vector in their respective tests, the null hypothesis of no co-integration $(r=0)$ among the variables is rejected at the $5 \%$ level of significance. In other words, both test statistics indicate the existence of one cointegrating relationship among variables (see table 4 and table 5)

Table 4: Johansen co-integration tests (Trace)

\begin{tabular}{||lccccc||}
\hline Null hypothesis & $\begin{array}{l}\text { Alternative } \\
\text { hypothesis }\end{array}$ & Eigen value & $\begin{array}{l}\text { Trace } \\
\text { statistic }\end{array}$ & $\begin{array}{l}\text { Critical } \\
\text { Value(5\%) }\end{array}$ & Prob.*** $^{* *}$ \\
\hline $\mathrm{r}=0^{*}$ & $\mathrm{r} \geq 0$ & 0.832604 & 88.08627 & 69.81889 & 0.0009 \\
$\mathrm{r} \leq 1$ & $\mathrm{r} \geq 1$ & 0.383785 & 29.10237 & 47.85613 & 0.7635 \\
$\mathrm{r} \leq 2$ & $\mathrm{r} \geq 2$ & 0.200912 & 13.12510 & 29.79707 & 0.8858 \\
$\mathrm{r} \leq 3$ & $\mathrm{r} \geq 3$ & 0.128374 & 5.723726 & 15.49471 & 0.7279 \\
$\mathrm{r} \leq 4$ & $\mathrm{r} \geq 4$ & 0.035409 & 1.189702 & 3.841466 & 0.2754 \\
\hline \hline
\end{tabular}

Source: E-views 7 output. Trace test indicates 1 co-integration equation(s) at the 0.05 level, $*$ denotes rejection of the hypothesis at the 0.05 level, **MacKinnon-Haug-Michelis (1999) p-values and $\mathrm{r}$ denotes the rank of long run matrix

Table 5: Johansen co-integration tests (Max-Eigen)

\begin{tabular}{|c|c|c|c|c|c|}
\hline Null hypothesis & $\begin{array}{l}\text { Alternative } \\
\text { hypothesis }\end{array}$ & Eigen value & $\begin{array}{c}\text { Max-Eigen } \\
\text { statistic }\end{array}$ & $\begin{array}{c}\text { Critical } \\
\text { value (5\%) }\end{array}$ & Prob.** \\
\hline $\mathrm{r}=0^{*}$ & $\mathrm{r}=1$ & 0.832604 & 58.98389 & 33.87687 & 0.0000 \\
\hline$r=1$ & $r=2$ & 0.383785 & 15.97728 & 27.58434 & 0.6678 \\
\hline$r=2$ & $r=3$ & 0.200912 & 7.401369 & 21.13162 & 0.9364 \\
\hline$r=3$ & $r=4$ & 0.128374 & 4.534025 & 14.26460 & 0.7991 \\
\hline$r=4$ & $\mathrm{r}=5$ & 0.035409 & 1.189702 & 3.841466 & 0.2754 \\
\hline
\end{tabular}

Source: E-views 7 output. Max-Eigen test indicates 1 co-integration equation(s) at the 0.05 level, ${ }^{*}$ denotes rejection of the hypothesis at the 0.05 level, **MacKinnon-Haug-Michelis (1999) p-values and $r$ denotes the rank of long run matrix

\subsection{VECM Short Run and Long Run Causality Results}

In the previous co-integration analysis the variables under consideration are found to be co-integrated, this suggests the existence of at least unidirectional causality between the variables but it does not provide the direction of causality (Engel and Granger, 1987). However, since the lagged residuals which are constructed from co-integrated equations provide an additional channel through which causality might revealed and also direct us to differentiate between short run and long run causality, the inclusion of error correction term in testing 
causal relationship among variables is very much important.

Table 6 presents the results of causality based on error correction models. Accordingly it provides direction of causation, the t-statistics for the error-correction terms and Chi-square statistics for the joint significance of the lagged independent variables based on Wald test respectively in the causality equations. The statistical significance of the error-correction term and the Ch-square statistic respectively indicate the presence of longrun and short-run causality.

Table 6: Causality Results Based on Error Correction Models

\begin{tabular}{||l||l||l||l||l||}
\hline Direction of causation & $\begin{array}{l}\text { Error correction } \\
\text { Term t. Statistic }\end{array}$ & Prob. & $\begin{array}{l}\text { Ch-square } \\
\text { statistic }\end{array}$ & Prob. \\
\hline \hline From Agricultural Export to GDP & -1.147654 & 0.2534 & 1.242655 & 0.2650 \\
From GDP to Agricultural Export & $-3.131421^{*}$ & 0.0045 & 0.731530 & 0.3924 \\
\hline From Industrial Exports to GDP & -1.147654 & 0.2534 & 0.333324 & 0.5637 \\
From GDP to industrial Export & $-3.744876^{*}$ & 0.0010 & 2.915668 & 0.0877 \\
\hline From service Exports to GDP & -1.147654 & 0.2534 & 0.218550 & 0.6401 \\
From GDP to service Export & $-5.885740^{*}$ & 0.0000 & $9.465248^{*}$ & 0.0021 \\
\hline \hline
\end{tabular}

Note: $*$ indicates significance at $5 \%$ level

The result in the above table 6 indicates the presence of short run and long run causal relationships between economic growth, agriculture export, industry export and service export. Owing agriculture export and economic growth there is no causality between them in the short. Similarly there is no causality between industry and growth in the short run. However there is unidirectional causality between service export and growth which run from growth to service export. In the long run it is evident that the results support the hypothesis of long run causality from economic growth to agriculture export but the reverse causality from agricultural export to economic growth is not supported. It is also evident the results strengthen the hypothesis of long run causality from economic growth to industry export and service export but failed to reject the null hypothesis of industry and service export does not granger cause economic growth in the long run.

Uni-directional causality from economic growth to export is accordance with the advocate of the opposite causality channel, in which the self-propelled growth of the domestic economy leads to improved competitiveness and eventually to the expansion of exports. Therefore, this finding is also consistent with the findings of (Thornton, 1996; Ewetan and Okudua, 2012; Ugwuegbe and Uruakpa, 2013; Armand Gilbert, et al 2013).

\subsection{Variance Decompositions}

Variance decomposition equipped us with information regarding the magnitude of relationship and the direction of causation both in the short run and long run. For instance, if disaggregate exports are important for economic growth; the impact of the shocks on disaggregate exports should be significant on growth and conversely if the growth in GDP is important to disaggregate exports; the impact of the shocks on GDP should be significant on disaggregate exports.

The result portrays how much an economic growth own shock is explained by movements in its own variance and the other variable. Both in the short run and long run the variation in the fluctuation in economic growth is explained significantly by its own shock. In the short run, after three periods, 97.61 percent of variation in the fluctuation of LRGDP explained by its owns shock and after eighteen periods 89.76 percent of forecast error variance of LRGDP explained by owns shock but during this period 3.98 percent, 3.03 and 3.12 percent of forecast error variance of LRGDP explained by the innovations of agriculture, industry and service export respectively.

Table 7: Variance decomposition of LRGDP:

\begin{tabular}{|c||c||c||c||c||c||c||}
\hline Period & S.E. & LRGDP & LRAX & LRIX & LRSX & LRIM \\
\hline \hline 1 & 0.041753 & 100.0000 & 0.000000 & 0.000000 & 0.000000 & 0.000000 \\
\hline 3 & 0.072121 & 97.60950 & 0.157245 & 1.105051 & 0.905631 & 0.222569 \\
\hline 9 & 0.138427 & 93.01850 & 2.092483 & 2.864758 & 1.912946 & 0.111312 \\
\hline 18 & 0.225277 & 89.75860 & 3.978720 & 3.025086 & 3.124723 & 0.112868 \\
\hline 21 & 0.253699 & 89.35760 & 4.232875 & 2.923405 & 3.354383 & 0.131740 \\
\hline 24 & 0.282468 & 89.11110 & 4.393936 & 2.827676 & 3.520634 & 0.146652 \\
\hline 28 & 0.321878 & 88.91532 & 4.526203 & 2.724409 & 3.674025 & 0.160047 \\
\hline 32 & 0.363037 & 88.79610 & 4.609015 & 2.649074 & 3.777638 & 0.168176 \\
\hline 36 & 0.406450 & 88.71343 & 4.666944 & 2.595112 & 3.851222 & 0.173289 \\
\hline 40 & 0.452563 & 88.65044 & 4.710905 & 2.555759 & 3.906098 & 0.176794 \\
\hline 43 & 0.464562 & 88.63685 & 4.720346 & 2.547583 & 3.917704 & 0.177514 \\
\hline \hline
\end{tabular}

Source: calculation by author using Eviews 7 
In such way compared with industry export the shock in agriculture and service export explained important variation of fluctuation in GDP. However, since the shock in disaggregate export explained insignificant variation of fluctuation of economic growth both in the short run and long run, it does not encourage saying agriculture, industry and service export plays more important role in forecasting and accelerating economic growth in Ethiopia separately.

Alternatively the variance decomposition of LRAX and variance decomposition of LRIX signify the shock in economic growth explained significant variation in the forecast error variance of LRAX and of LRIX in the long run and also variance decompositions of LRSX shows the innovation in economic growth explained significant variation in the forecast error variance of LRSX both in the short run and long run. Thus, it encouraged to say economic growth promotes agriculture, industry and service export in Ethiopia separately.

\subsection{Impulse Response Function}

An impulse response functions signify the response of the system over time to a shock to each of the variables in the system and measure the importance of next period shocks for future values of a time series. It also provides information concerning the sign of the causal relationship among the variables and how long would the effect of the shocks persist in the system.

Table 8 presents the result of impulse response function of economic growth (LRGDP) to a one-standard deviation shocks in GDP, agriculture export, industry export, service export and import over a 10 years period. A one standard deviation innovation of disturbance originating from real GDP, future LRGDP increases by 0.04 percent in the first year and further rise in the fifth year to 0.044 and reaches to 0.05 at the end of time horizon. Table 8: Impulse responses to generalized One S.D innovation response of LRGDP:

\begin{tabular}{|c|c|c|c|c|c|}
\hline Period & LRGDP & LRAX & LRIX & LRSX & LRIM \\
\hline 1 & 0.041753 & 0.018423 & 0.011011 & 0.007345 & 0.023574 \\
\hline 2 & 0.039754 & 0.017734 & 0.005542 & 0.009124 & 0.022026 \\
\hline 3 & 0.041874 & 0.021035 & 0.005442 & 0.009367 & 0.024538 \\
\hline 4 & 0.042919 & 0.022931 & 0.004087 & 0.010070 & 0.026222 \\
\hline 5 & 0.044181 & 0.024905 & 0.003313 & 0.010858 & 0.028081 \\
\hline 6 & 0.045415 & 0.026692 & 0.002758 & 0.011749 & 0.029869 \\
\hline 7 & 0.046665 & 0.028343 & 0.002443 & 0.012684 & 0.031599 \\
\hline 8 & 0.047915 & 0.029851 & 0.002308 & 0.013630 & 0.033244 \\
\hline 9 & 0.049164 & 0.031226 & 0.002317 & 0.014562 & 0.034798 \\
\hline 10 & 0.050410 & 0.032480 & 0.002433 & 0.015463 & 0.036258 \\
\hline
\end{tabular}

Source: calculation by author using Eviews 7

One standard deviation innovation of disturbance coming from agriculture export leads to 0.018 percent increase in real GDP in the first year and further increases to 0.02 percent in the fifth year and bit by bit reaches to 0.03 percent at the end of time horizon. Likewise a one-standard deviation shocks disturbance originating from industry and service export leads to 0.01 percent and 0.007 percent increase in real GDP respectively in the first period, 0.003 percent and 0.01 rise in real GDP respectively in the fifth years period and 0.002 percent and 0.015 percent increase in real GDP respectively at the end of time horizon.

\section{CONCLUSION AND IMPLICATION}

To accomplish the objectives of the study econometrics methods of analysis has been employed over the period 1974/75 to 2016/17. Specifically after Johansen co-integration test witnessed the variables are co-integrated; VECM employed to examine the causality between sectors export and economic growth both in the short run and long run. The findings reveal in the long run the existence of unidirectional causality which runs from economic growth to agriculture, industry and service export separately. In the short run economic growth does cause service export however, it does not cause agriculture and industry export separately. That is there is unidirectional causal relation only between service export and economic growth and the direction of causation runs from economic growth to service export. And hence the reason for the existence of positive and significant long run link between sectors' export and economic growth is not as a result of export leaded growth rather it is the economic growth caused export to grow. In sum this finding is quite supportive to the ideas of growth lead export (GLE) hypothesis and against the ideas of export lead growth (ELG) hypothesis. And hence to expand and diversify export economic growth should be Strengthen and diversifying in Ethiopia.

\section{Declarations}

\section{Acknowledgements}

The authors are thankful to almighty God. We are also grateful to national bank of Ethiopia and ministry of finance and economics development of Ethiopia, with their all staff members of them, for their valuable assistance during data collection. 


\section{Funding}

Not applicable

\section{Availability of data and materials}

The data that support the findings of this study can be obtained from the authors based on request.

\section{Authors' contributions}

The first author generates idea, formulate methodology, undertaken the data collection, analyzed and interpreted it up. The second author read and revised the manuscript. Both authors read and approved the final manuscript.

\section{Competing interests}

The authors declare that they have no competing interests.

\section{REFERENCE}

Anwar, Muhammad S. and R. K. Sampath (2000) "Exports and Economic Growth." Indian Economic Journal. January - March 1999-2000. Vol. 47, No.3. pp. 79-88.

Balassa, B.(1978), "Exports and Economic Growth: Further Evidence”; Journal of Development Economics 5: 181-189.

Chu, W., (1988), “Export-led growth and import dependence”, Journal of Development Economics 28, $265-276$. North-Holland

Dawson, P.J. (2005), “Agricultural exports and economic growth in less developed Countries". AgriculturalEconomics, No.33, pp. 145 - 152.

Dickey, D. and Fuller W. (1981), "Likelihood ratio statistics for autoregressive time series with a unit root".Econometrica, No.49, pp.1057 - 1072.

Engel,R.F. and C.W.J. Granger. (1987), "Co-integration and Error Correction: Representation, Estimation and Testing”; Econometrica 55(2):251-276.

Ewetan and Okodua (2013), "Econimetric Analysis of Exports and Economic Growth in Nigeria". E-mail: HYPERLINK "mailto:banji.ewetan@covenantuniversity.edu.ng" banji.ewetan@covenantuniversity.edu.ng

Feder, G. (1982), “On Exports and Economic Growth”; Journal of Development Economics 12:5973.

Fernando, U.F.N. (1988), “The Relationship between Exports and Economic Growth in Sri Lanka:an Empirical Investigation", Central Bank Staff Studies, Vol.18, No. 1 \& 2. pp. 97-126.

Granger, C.W.J. (1969), "Investigating causal relations by econometric and cross-spectral Method".Econometrica, 37(3), pp. 424 - 438.

Gujarati, D. (1995), “Basic Econometrics”, 3rd Edition, New York: McGraw-Hill

Hailegiorgis B.(2012), “Export-Led Growth in Ethiopia”: America Journal of Economics. P-ISSN 2166-4951.

Idowu, K.O. (2005), "A Preliminary Investigation into the Causal Relationship between Exports and Economic Growth in Nigeria"; CBN Economic and Financial Review 43(3): 29-50.

Johansen, S. (1988), "Statistical analysis of cointegration vectors". Journal of Economic Dynamics andControl, No.12, 231 - 254.

Johansen, S. and Juselius, K. (1990), "Maximum likelihood estimation and inference on Co-integration with application to the demand for money". Oxford Bulletin of Economic and Statistics, No.52, pp. 169 - 210.

Khalafalla, K.Y. and Webb, W.J., 2000, "Exports and Economic Growth UnderStructural Change": A Cointegration Analysis of Evidence from Malaysia. International Agricultural Trade and Research, Working paper 00-1.

Mohamed, Yee Liew and Mzee (2012), "Export Trade and Economic Growth in Tanzania". Journal of Economics and Sustainable Development. Vol.3, No.12.

Soressa (2013) "Exports, Domestic Demand and Economic Growth in Ethiopia". Journal of Economics and International Finance. Vol. 5(9), pp. 357-372

Tyler, W. (1981), "Growth and export expansion in developing countries", Journal of Development Economics 9, pp $121-30$

Ugwuegbe and Uruakpa(2013), "The Impact of Export Trade on Economic Growth In Nigeria". International Journal of Economics, Business and Finance. Vol. 1 PP: 327-34166.

Wong Hock (2006), "Exports, Domestic Demand and Economic Growth in China": Granger causality analysis, Some Empirical Evidence, J. Econ. Cooperation.

World Bank (2016), "www.ethiopiainvestor.com-ethiopia-economic". 